\title{
Adult patients with congenital malformations of the mitral valve
}

\author{
OKristina Marić Bešić* \\ CMaja Strozzi, \\ -Željko Baričević, \\ CVlatka Rešković \\ Lukšić, \\ (1) Jadranka Šeparović \\ Hanževački, \\ CMargarita Brida
}

University of Zagreb School of Medicine, University Hospital Centre Zagreb, Zagreb, Croatia

\section{RECEIVED:}

May 2, 2018

ACCEPTED:

May 10, 2018

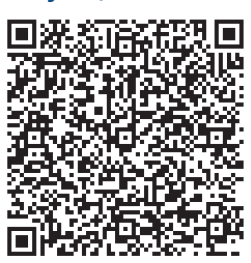

$\square$ Cardiologia Croatica 2018;13(5-6):194.
KEYWORDS: congenital mitral valve, evaluation, treatment.

CITATION: Cardiol Croat. 2018;13(5-6):194. | https://doi.org/10.15836/ccar2018.194

*ADDRESS FOR CORRESPONDENCE: Kristina Marić Bešić, Klinički bolnički centar Zagreb, Kišpatićeva 12, HR-10000 Zagreb, Croatia. / E-mail: kmaricbesic@gmail.com

ORCID: Kristina Marić Bešić, https://orcid.org/0000-0002-4004-7271 • Maja Strozzi, https://orcid.org/0000-0003-4596-8261 Željko Baričević, https://orcid.org/0000-0002-5420-2324 • Vlatka Rešković Lukšić, https://orcid.org/0000-0002-4721-3236 Jadranka Šeparović Hanževački, https://orcid.org/0000-0002-3437-6407 • Margarita Brida, https://orcid.org/0000-0001-8754-8156

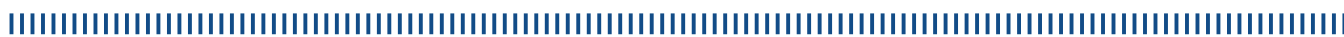

Congenital anomalies of the mitral valve may be isolated lesions or associated with other complex congenital heart defects. Each level of the mitral valve can be affected from the annulus, leaflets, chordae tendineae and papillary muscles. Isolated mitral stenosis is one of the rarest form of congenital heart disease $(0.6 \%)$ but can be associated with other left side abnormalities ${ }^{1}$. Most cases of mitral stenosis are diagnosed in early childhood leading to mitral valve repair or replacement. Unoperated congenital mitral stenosis in an adult will be limited to rather mild or moderately severe stenosis with symptoms and complications identical to rheumatic mitral valve disease. Mitral valve regurgitation due to primary mitral valve prolapse has a prevalence of $2.4 \%$ and is the most frequently diagnosed cardiac valvular abnormality. It occurs mostly as an isolated valve dysfunction but can be associated with connective tissue diseases or other cardiac abnormalities. Echocardiography is the definite diagnostic method for congenital mitral valve anomalies but in presence of multiple lesions, hemodynamic assessment by cardiac catheterization can be useful. To emphasize that the management of adult patients with congenital mitral valve disease can be challenging we present two patients.

The first is 24-year-old female patient with a mechanical mitral valve who was operated in childhood because of mitral regurgitation. She has reduced left ventricular ejection fraction and her pregnancy was complicated with AV nodal reentry tachycardia requiring electrophysiology and catheter ablation before and after childbirth.

The second patient is 30-year-old female with a parachute mitral valve. Stress echocardiography revealed severe mitral stenosis which presents a contraindication for her planned pregnancy.

In conclusion, the decision for medical management or the need and timing of surgical intervention in these patients must be made according to clinical presentation, symptoms and noninvasive or invasive evaluation.

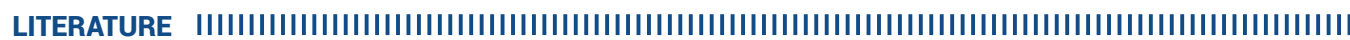
1. Gatzoulis MA, Webb GD, Daubeney PEF. Diagnosis and management of adult congenital heart disease, $2^{\text {nd }}$ Ed. Saunders, PA: Elsevier, 2011. 